\section{The Threat to Norwegian as an Academic Language}

\section{Birgit Brock-Utne}

Birgit Brock-Utne is professor of comparative and international education at the University of Oslo. Address: Institute for Educational Research, PB 1092 Blindern, N-0317 Oslo, Norway. E-mail: birgit.brock-utne@ped.ui.no.

$\mathrm{I}_{\mathrm{i}}^{\mathrm{n}}$ I99I Norwegian state institutions gained the option of introducing "performance salary" as part of local salary negotiations. One institute, in the humanities, began rewarding academic staff for their published books and articles. At the University of Oslo Institute of Philosophy in I997, an author of a book published in Norwegian received a bonus of 7,000 NOK (ca. \$I,IOO), while an author of a book published in English received a bonus of 15,000 NOK. An academic staff member who edited a scholarly book or professional journal in Norwegian received a bonus of 2,000 NOK. If the book or journal was published in the English language, the editor got a bonus of 5,000 NOK. The author of a doctoral thesis written in Norwegian received a bonus of 7,000 NOK, while an author of a doctoral thesis written in English received a bonus of I5,000 NOK. The author of an article in a professional, refereed journal received I,००० NOK if the article was in Norwegian and 7,000 NOK if the article was in English.

The presentation of this strategy before the Institute for Educational Research in 1997 produced protests among our academic staff. We saw the system as a danger both to our country's language and to a university's obligation to the rest of society. We saw it as a threat to democracy. Unfortunately, the case in point at the Institute of Philosophy began an ongoing policy trend.

\section{Publish in English or Perish}

In 2004 the Norwegian Association of Higher Education Institutions published a dossier called Vekt på forskning (Emphasis on Research), which instituted a reward system dividing journals and publishing companies into three levels: level zero-no reward given to the institution or researcher, including most publishing companies in developing countries even if they publish in English; level one-reward given; level two-a higher reward given, often three times higher than level one.

On the Internet one can find a list of 486 ranked publishing companies. Of these companies 55 are ranked at level two, while 43I companies are ranked at level one. No Norwegian publishing company is ranked at level two, not even the University Publishing Company or other academic publishers. More than 80 percent of the publishing companies ranked at level two are based in the United States (The Web site offering publication rankings is www.uhr.no/forskning/publiseringsut valget/om_vitenskapelig_publisering.) Points are given for single-authored books published by a publishing company ranked at level one ( 5 points), and single-authored books published by a publishing company ranked at level two (8 points). Chapters in books published by a publishing company ranked at level one are rewarded with 0.7 points, at level two with I point. In 2006 each point created a reward of 40,000 NOK (US\$6,500), which was received by the university. Normally the university keeps 25 percent and transfers the rest to faculties with academic staff members who have generated the revenue. A faculty keeps some of the money and distributes the rest to various departments. The departments determine what to give a qualified academic staff member as well as what to include in a research fund for which all academic staff can apply. At the Institute for Educational Research, academic staff who have earned the points will obtain about a Ioth of the sum for their own research purposes.

Regarding academic journals, I,758 ranked journals are listed, among which a Ioth are ranked at level two and the rest at level one. Only four of the many peer-reviewed academic journals published in Norwegian have been ranked at level two. Within the field of educational research no academic journal with articles in a language other than English has been ranked at level two. Scholarly articles at level one are rewarded with one point and at level two with three points. This system has now been instituted and forms part of the basis for university funding.

\section{Discouraging Norwegian academics from publish-} ing in the national language will deteriorate academic Norwegian and prevent the further development of vocabulary.

\section{The Higher Education Law}

The May I2, I995, law of Norwegian higher education contained the following paragraph: "The language of instruction in Norwegian universities and colleges is normally Norwegian" ( $\sqrt{ } 2.7)$. The paragraph was inserted in the law after quite a lot of pressure from the Norwegian Language Council. At one point the Ministry of Education tried to delete the paragraph, but Parliament put it back in. In 2002 a new law of Norwegian higher education was proposed that again suggested doing away with $\ 2.7$. There were protests against the deletion of this paragraph from the University of Tromsø, from the Norwegian Language Council, and from some academics. Nevertheless, the paragraph was taken out of the newest (August I, 2005) law of Norwegian higher education-because, it was argued, of the current internationalization of universities. Without this important paragraph we cannot demand that non-Norwegianspeaking university professors learn the Norwegian language 
in order to teach and tutor our students in our language and thus cannot keep academic staff from being forced to hold their meetings in English. This development is also a threat to Norwegian as an academic language.

\section{CONCLUSION}

This case shows how a less extensive European language, like Norwegian, is threatened as an academic language. Discouraging Norwegian academics from publishing in the national language will deteriorate academic Norwegian and prevent the further development of vocabulary. Our situation corresponds to the struggle African academics face in discussing academic matters in African languages, given the absence of academic concepts in their languages. All languages develop through use; through disuse they stagnate and fail to develop. The Norwegian case also reveals the threat to Norwegian publishing houses. The lack of weight given journals or chapters of books published in developing countries discourages Norwegian academics from using such publication channels. The absence of a bonus for publishing in nonrefereed journals or newspapers also discourages Norwegian academics from such actions. These effects represent a threat to democracy and to the enlightenment of the public.

A discussion about the anglicization of European universities is under way in many European countries and is currently lively in Norway, Sweden, and Denmark. Norwegian academics seem more prepared to defend their national language as an academic language than are colleagues in some other European countries. A petition, "To the defense of Norwegian as a language of research," signed May 5, 2006, by 223 wellknown Norwegian professors in the humanities and social sciences was published in the country's largest newspaper, Aftenposten. The petition referred to the official statement from the University of Oslo declaring that universities have a fundamental responsibility to preserve and develop Norwegian as an academic language. The statement launched the principle that no connection should exist between financial reward and the language of publication. The petition supported this principle and argued that it had to be established as a norm for the whole university and college sector. Professors who signed the petition challenged the academia of Norway to rethink the reward system that had been formed. The social sciences and humanities need provisions that do not discriminate against Norwegian. The petition has, however, as yet (April 2007) had no effect. The reward system continues.

The engagement of many Norwegian academics in defending Norwegian as an academic language contrasts with the attitude of many Dutch academics. In I989, the minister of education in the Netherlands proposed, with overwhelming support from the academic community, that English should be the sole medium of instruction in all Dutch universities. The proposal met with harsh criticism when it was presented in Parliament, however. Parliament insisted on regulating the language issue because it did not trust the minister and the academics. Parliament thus passed an amendment to the university law stating that no courses can be offered in another language if it is not also offered in Dutch. This action was seen as a retreat for professors who wanted more English-language instruction in Dutch higher education. Nevertheless, the expansion of master's courses taught in English has continued in Dutch higher education. The threat to European languages as academic languages posed by the increased anglicization of academia needs to be watched given the challenge to the academic strength of some European languages.

Author's note: In an article to be published in the International Review of Education (no. 6, 2007), I have gone deeper into these issues.

\section{Student Dissent and Politics at the University of São Paulo}

\section{SIMON SCHWARTZMAN}

Simon Schwartzman is president of the Institute for Studies on Labor in Society in Rio de Janeiro, Brazil. E-mail: simon@schwartzman.org.br.

$\mathrm{O}$ May 3, 2007, a group of students took over the rector's office at the University of São Paulo (USP). The group claims to represent the university's 80,000 students and does have the support of the unions of the university's administrative personnel, the teachers union, and some professors.

\section{Universidade de São Paulo}

USP is a state institution, supported by the state of São Paulo and one of the most important in Latin America. One-third of its students are in master's and $\mathrm{PhD}$ programs. There are I5,000 administrative employees and about 5,000 academics, most of them with a doctoral degree. In 2004, the university granted 2,100 PhDs, 3,300 MAs, and 5,500 professional degrees in all fields of knowledge at 68 units, on the main campus in the city of São Paulo and on campuses in other cities in the state.

The university receives 5 percent of the state of São Paulo's tax revenues, which amounted last year to about 2.2 billion reais (US\$I.I billion). Within its budget, the university is free to use the funds as it sees fit and can also obtain revenues from other sources. To enter the university, students need to pass an exam that can be extremely competitive in fields like medicine, engineering, or law. There is no tuition. Most doctoral students are able to get fellowships as stipends. Professors at USP are the major recipients of research grants from the Brazilian 